\title{
NOVEL APPROACH OF EXTRACTION AND CHARACTERIZATION OF OKRA GUM AS A BINDER FOR TABLET FORMULATION
}

\author{
SHAYERI CHATTERJEE, RANA MAZUMDER*
}

Department of Pharmaceutics, Faculty of Pharmacy, Calcutta Institute of Pharmaceutical Technology and Allied Health Sciences, Howrah - 711 316, West Bengal, India. Email: ranapharma.mazumder@gmail.com

Received: 11 August 2018, Revised and Accepted: 13 September 2018

\section{ABSTRACT}

Objective: The major objective of the present investigation was to extract a natural polymer (okra gum) with its characterization as pharmaceutical binder and to formulate, develop, and evaluate the compression-coated tablet using okra as binder along with synthetic hydrophilic polymers like various grades of hydroxypropyl methylcellulose (HPMC).

Methods: A novel extraction method was carried out using fresh unripe pods of okra (ladies finger) with the aid of organic solvents and its characterization was done. The core tablets were prepared by direct compression method which was compression coated with okra gum and HPMC.

Results: After the extraction of the okra gum was carried out, the yield of mucilage obtained was $10 \%$. It is considered as a proof for the purity of the mucilage extract. The above study reveals that the polymers were subjected to the Fourier transform infrared and differential scanning calorimetry thermogram had no significant interactions between the drug and the polymers. The characterization of the new polymer okra showed that it has swelling properties, and in spite of being a hydrophilic polymer, it can be successfully used in pharmaceutical formulation as a good binder.

Conclusion: In the present aspect of the study was to evaluate the efficacy of okra gum that has been used as a tablet binder. It is easily available and inexpensive. Okra gum as a binder produces tablet formulations with good physicochemical properties and good candidate for sustained release formulations.

Keywords: Natural polymer, Okra gum, Pharmaceutical formulations, Binder

(C) 2019 The Authors. Published by Innovare Academic Sciences Pvt Ltd. This is an open access article under the CC BY license (http://creativecommons. org/licenses/by/4. 0/) DOI: http://dx.doi.org/10.22159/ajpcr.2019.v12i1.29053

\section{INTRODUCTION}

Natural polymers are obtained from the plant sources. They are high molecular weight and water-soluble polymers composed of monosaccharide units and united by glucosidal bonds [1]. Some of the known polymers are pectin, guar gum, acacia, locust bean gum, tamarind gum, okra gum, etc. The uses of natural gums have increased a lot nowadays, due to their biodegradability in the body, their nontoxic nature and sometimes they provide a rate retarding effect on the release of drugs in a particular dosage form. Okra (Abelmoschus esculentus) [2] is the only vegetable crop of significance in the Malvaceae family and is very popular in the Indo-Pak subcontinent. It is an oligo purpose crop, but it is usually consumed for its green tender fruits as a vegetable in a variety of ways. These fruits are rich in vitamins, calcium, potassium, and other mineral matters. The mature okra seed is a good source of oil and protein has been known to have superior nutritional quality. Okra seed oil is rich in unsaturated fatty acids such as linoleic acid which is essential for human nutrition. They are also known as ladies finger. It is used as a binder and produces tablet formulations with good and optimum physicochemical properties. It also retards the release of drug, increasing the half-life of a successfully used in controlled/sustained release tablet formulations and is also a hydrophilic polymer. It is also used as retardant, disintegrant, suspending agent, and matrix forming material. It is easily available and is quite economical. Being a natural polymer, it exhibits the property of biodegradation and mucoadhesion. Okra gum produces high viscosity mucilage at low concentrations. In continuation with the ongoing research on okrabased formulations, the major objective of the present investigation was to prepare to formulate, develop, and evaluate the compression- coated tablet using okra gum extracted from okra as binder along with synthetic hydrophilic polymers like various grades of hydroxypropyl methylcellulose (HPMC) and compare their various parameters.

\section{METHODS}

Fresh unripe pods of okra (ladies finger) were purchased from Kolkata, West Bengal, India. Losartan potassium was gifted from Caplet India Pvt., Ltd., Recjuani, Kolkata, West Bengal, India. HPMC - 5cps, 15cps, and $50 \mathrm{cps}$, talc, and magnesium stearate were purchased from Merck Specialties Pvt., Ltd., Mumbai, India. Microcrystalline cellulose (MCC), sodium starch glycolate, lactose, acetone, and alcohol were purchased from Loba Chemicals Pvt., Ltd., Mumbai, India.

\section{Novel method of extraction of okra}

Fresh unripe pods of okra (ladies finger) were obtained from the local market. The pods were cut into very thin slices longitudinally and the seeds were removed and then soaked in the distilled water for $24 \mathrm{~h}$, the swollen slices were then squeezed through muslin bags to obtain aqueous extract. To the aqueous extract, thrice the volume of acetone was added to precipitate the mucilage. The mucilage was separated and acetone was removed by vacuum filtration. A part of the mucilage was kept aside and a part was subjected to solar drying [3].

\section{Characterization method of okra gum}

Physicochemical characterization of okra mucilage

The aqueous extract was mixed with Molisch's reagent followed by addition of sulfuric acid. The violet color ring appeared at junction, showing the presence of carbohydrates [4]. 
Organoleptic evaluation of isolated mucilage

Isolated mucilage was characterized for color, odor, taste, etc. [5].

\section{Determination of purity of extracted gum}

Corresponding tests for alkaloids, proteins, tannins, and fats were carried out.

\section{Ash value}

Total ash value was determined after the incineration of the sundried gum and the result was calculated [6] using the formula

Total Ash value $=\frac{\text { Weight of the ash }}{\text { Weight of the gum }} \times 100$

\section{Solubility behavior}

The mucilage was sundried that led to the formation of a powdery material, which was shaken with different solvents such as water, alcohol, and acetone, and solubility was further determined [7].

\section{pH of mucilage}

The mucilage was weighed and dissolved in water separately to get a $1 \% \mathrm{w} / \mathrm{v}$ solution. The $\mathrm{pH}$ of solution was determined using digital $\mathrm{pH}$ meter [7].

\section{Swelling index}

The swelling index was calculated as per equation:

Swelling index $=\frac{\text { Final volume }- \text { initial volume }}{\text { Final volume }} \times 100$

\section{Surface tension}

It was determined by drop count method, using a stalagmometer. Surface tension was calculated as per equation: $\sigma_{\text {solution }}=\sigma_{\text {waterx }} \mathrm{m}$ (solution)/m (water).

Where, $m$ (solution)=Surface tension of solution, $m$ (water)=Surface tension of water

$\sigma_{\text {solution }}=$ Weight of solution, and $\sigma_{\text {water }}=$ Weight of water

\section{Viscosity}

It was determined [7] using Oswald's viscometer using the equation

$\mathrm{S}=\mathrm{w} \times \mathrm{t}_{\mathrm{s}} \rho_{\mathrm{s}} / \mathrm{t}_{\mathrm{w}} \rho_{\mathrm{s}}$ where, $\mathrm{s}=$ Viscosity of solution, $\mathrm{w}=$ Viscosity of water, $\mathrm{t}=$ Time, and $\rho=$ Density.

\section{Moisture content}

This was carried out after drying the mucilage under sun. The dried sample was taken and $1 \mathrm{~g}$ was weighed. After the weight was recorded, the sample was dried in a hot air oven at a temperature of $105^{\circ}$. The weight was recorded at regular time intervals and the percentage of moisture content [7] was calculated using the equation:

$$
\text { Moisture content }=\frac{\text { Initial weight }- \text { Final weight }}{\text { Initial weight }} \times 100
$$

\section{Bulk density}

Accurately weighed amount of the dried gum (10 g) was taken and kept in a bulk density apparatus. The volume was noted. Hence, the bulk density [8] was calculated using the formula: Bulk density=Weight of the powder/bulk volume.

\section{Tapped density}

The bulk density apparatus was subjected to consecutive tappings, after noting the bulk volume. The tapped volume was recorded.

Tapped density [8] was recorded by the following formula:
Tapped density=Weight of the powder/Tapped volume $\times 100$.

\section{Hausner ratio}

Tapped density and bulk density were measured and the Hausner's ratio was calculated using the formula: Hausner ratio=Tapped density/ Bulk density.

\section{Carr's index}

It was measured using the value of the bulk density and tapped density. $\mathrm{CI}=\mathrm{TD}-\mathrm{BD} / \mathrm{TDX}$ 100, where, $\mathrm{TD}=$ Tapped density and BD=Bulk density.

\section{Angle of repose}

A specific amount of powder was allowed to flow freely letting a conical heap to form. The following formula gives the angle of repose [9]: Angle of repose $(\operatorname{Tan} \theta)=h / r$, where, $\theta=$ Angle of repose, $h=$ Height of the heap of powder, and $r=$ Radius of the heap of powder.

\section{Infrared spectroscopy}

Using Perkin-Elmer 841, IR spectrophotometer obtained an IR spectrum of okra gum. The sample was prepared into a pellet with $1 \mathrm{~g}$ of KBR. The IR spectrum of okra gum is shown in Fig. 1.

\section{Differential scanning calorimetry (DSC)}

DSC of the dried and powdered extract was carried out, in Shimadzu DSC50 at a heating rate of $10^{\circ} \mathrm{C} / \mathrm{min}$ from $30^{\circ} \mathrm{C}$ to $300^{\circ} \mathrm{C}$ in nitrogen atmosphere (30 ml/min). The DSC thermogram of okra gum is shown in Fig. 2.

\section{Method and evaluation of okra gum binder-based tablets}

The fast disintegrating core tablets of losartan potassium were prepared by directcompression method [10]. The drug along with sodium starch glycolate (superdisintegrant) 3\%, 2\% talc, 2\% magnesium stearate, and adequate MCC was passed through sieve \#80 and core tablets of $200 \mathrm{mg}$ compressed on 10 station tablet machine. The core tablets were compression coated [11] with different coat formulations. The coating material was prepared by wet granulation technique using varying concentrations of okra gum, as a binder (in 3\% w/w, 4\% w/w, and 5\% w/w) and three grades of HPMC ( $5 \mathrm{cps}, 15 \mathrm{cps}$, and $50 \mathrm{cps})$ were used in various concentrations $(30 \%, 60 \%$, and $90 \%)$, magnesium stearate $(2 \%)$ and talc (2\%) were used as glidant and lactose was used as diluent which is shown in Table 1. Granules were dried at $50^{\circ}$ for $1 \mathrm{~h}$ in hot air oven. Dried granules were passed through sieve \#22 and were lubricated. 45\% of coating material granules was kept in die cavity and the core tablet was placed carefully on it in centered position and then remaining $55 \%$ of coating material granules were added to cavity and compressed into tablet. Physicochemical properties of compression-coated tablets were evaluated which are shown in Table 4.

\section{RESULTS AND DISCUSSION}

After the extraction of the okra gum was carried out, the yield of mucilage obtained was $10 \%$. The sample was subjected to identification tests which showed the presence of carbohydrates. However, it gave negative tests for alkaloids, tannins, proteins, and fats confirming the presence of mucilage. It is considered as a proof for the purity of the mucilage extract. The moisture content was $14.96 \%$, showing the hygroscopic nature of

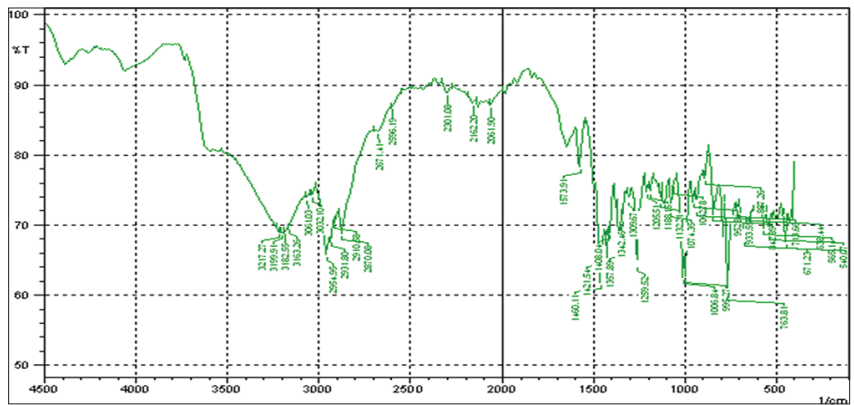

Fig. 1: Fourier transform infrared spectra of losartan potassium and polymers (okra gum, hydroxypropyl methylcellulose [HPMC] 5cps, HPMC 15cps, and HPMC 50cps) 


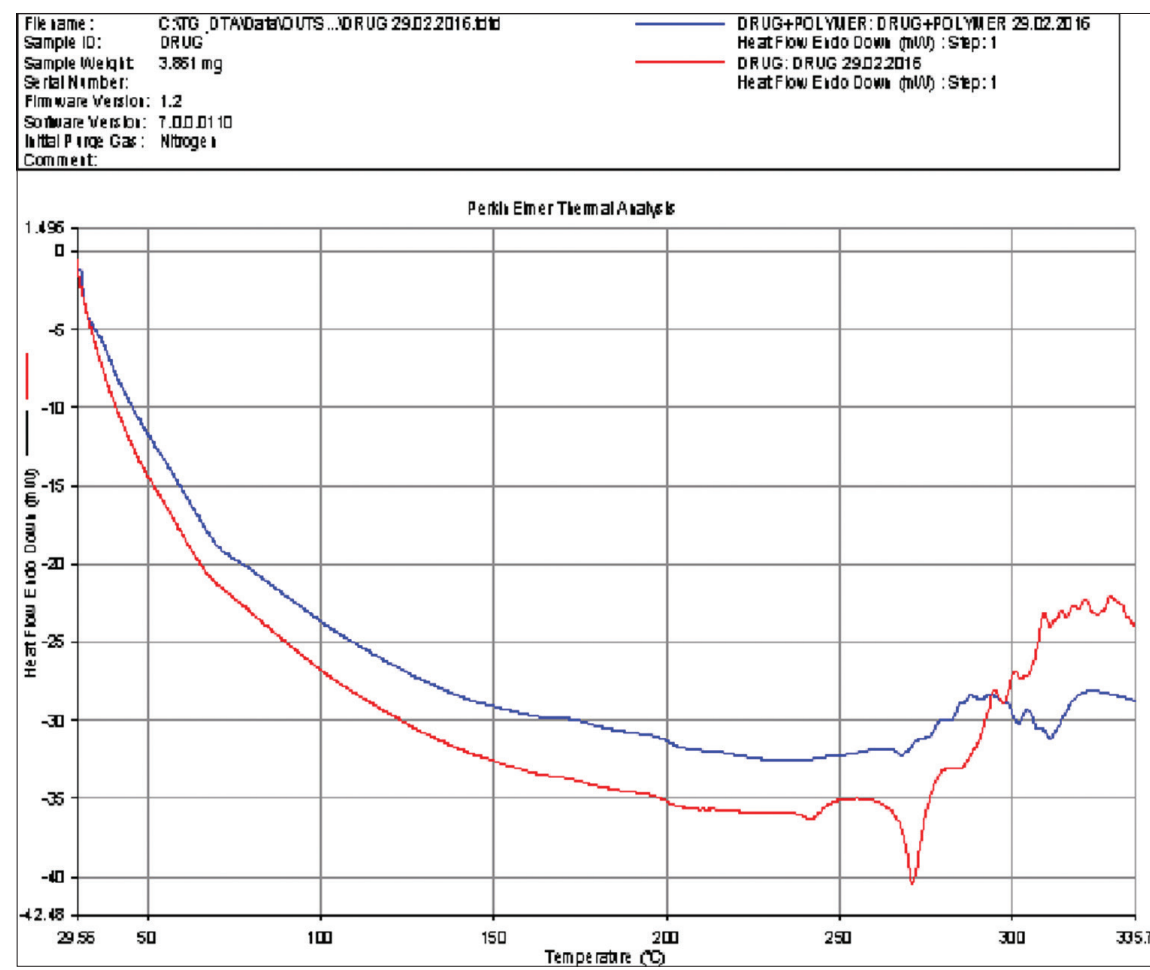

Fig. 2: Differential scanning calorimetry thermogram of losartan potassium and polymers comparison

Table 1: Formulation chart for compression-coated tablets

\begin{tabular}{|c|c|c|c|c|c|c|c|c|c|}
\hline $\begin{array}{l}\text { Formulation } \\
\text { code }\end{array}$ & $\begin{array}{l}\text { Weight of } \\
\text { core tablet (mg) }\end{array}$ & $\begin{array}{l}\text { Okra } \\
\text { mucilage (\%) }\end{array}$ & $\begin{array}{l}\text { HPMC } \\
5 \operatorname{cps}(\%)\end{array}$ & $\begin{array}{l}\text { HPMC } \\
\text { 15cps (\%) }\end{array}$ & $\begin{array}{l}\text { HPMC } \\
50 \operatorname{cps}(\%)\end{array}$ & $\begin{array}{l}\text { Magnesium } \\
\text { stearate (\%) }\end{array}$ & Talc (\%) & $\begin{array}{l}\text { Lactose } \\
\text { (mg) }\end{array}$ & $\begin{array}{l}\text { Total } \\
\text { weight (mg) }\end{array}$ \\
\hline F1 & 200 & 3 & 30 & - & - & 2 & 2 & q.s & 500 \\
\hline $\mathrm{F} 2$ & 200 & 4 & 60 & - & - & 2 & 2 & q.s & 500 \\
\hline F3 & 200 & 5 & 90 & - & - & 2 & 2 & q.s & 500 \\
\hline F4 & 200 & 3 & - & 30 & - & 2 & 2 & q.S & 500 \\
\hline F5 & 200 & 4 & - & 60 & - & 2 & 2 & q.s & 500 \\
\hline F6 & 200 & 5 & - & 90 & - & 2 & 2 & q.s & 500 \\
\hline F8 & 200 & 4 & - & - & 60 & 2 & 2 & q.s & 500 \\
\hline F9 & 200 & 5 & - & - & 90 & 2 & 2 & q.s & 500 \\
\hline
\end{tabular}

Table 2: Characterization of the okra gum

\begin{tabular}{lll}
\hline Sl. No. & Parameters & Report \\
\hline 1 & Color & Light brown \\
2 & Odor & Odorless \\
3 & Taste & Tasteless \\
4 & Carbohydrates & Present \\
5 & Proteins & Absent \\
6 & Tannins & Absent \\
7 & Fats & Absent \\
8 & Mucilage & Present \\
9 & Solubility & Soluble in water, insoluble in \\
& & organic solvents \\
10 & Swelling index & $120 \%$ \\
11 & Moisture content & $14.96 \%$ \\
12 & Total ash value & $7.5 \%$ \\
13 & pH & 5.85 \\
14 & Surface tension & $0.041 \mathrm{joule} / \mathrm{m}^{2}$ \\
& (0.25\% w/v of solution) & \\
15 & Viscosity (1\% gum) & $130 \mathrm{cps}$ \\
16 & Micromeritic study & \\
& Bulk density & $0.632 \mathrm{~g} / \mathrm{cc}$ \\
& Tapped density & $0.705 \mathrm{~g} / \mathrm{cc}$ \\
& Angle of repose & 28.09 \\
& Mean particle size & $53 \mu \mathrm{m}$ \\
\hline
\end{tabular}

the dried gum. It needs to be stored in an airtight container. The mucilage was found to be soluble in water and insoluble in acetone, ethyl alcohol, chloroform, and paraffin. Surface tension of $0.25 \% \mathrm{w} / \mathrm{v}$ solution of mucilage was found to be 0.041 joule $/ \mathrm{m}^{2}$. $\mathrm{pH}$ of $1 \%$ solution was found to be 5.85. Irregular particle size was found to be $53 \mu \mathrm{m}$. The viscosity of $1 \%$ okra mucilage was found to be $130 \mathrm{cps}$ at a speed of $50 \mathrm{rpm}$. The extracted mucilage had a light brownish to light buff color and that of the dried sample was greenish-yellow color and was odorless and tasteless. The okra-based formulation is shown in Table 1 and total ash value was found to be $7.5 \%$ which are shown in Table 2 . The micromeritic studies showed that the powder and granules had a good flow property, as shown in Table 3. The above study reveals that the polymers were subjected to the Fourier transform infrared and DSC thermogram had no significant interactions between the drug and the polymers shown in Figs. 1 and 2 for the preparation of tablets. All the physicochemical properties of tablets were within the limits which are shown in Table 4. The characterization of the new polymer okra showed that it has swelling property formulation as a good bindery, and in spite of being a hydrophilic polymer, it can be successfully used in pharmaceutical formulation as a good binder.

\section{CONCLUSION}

In the present aspect of the study was to evaluate the efficacy of okra gum that has been used as a tablet binder. It is a natural polymer 
Table 3: Angle of repose, bulk and tapped density, Carr's index, and Hausner's ratio

\begin{tabular}{lllll}
\hline Formulation code & Angle of repose & Bulk density & Tapped density & Carr's index \\
\hline F1 & $24.03 \pm 0.78$ & $0.425 \pm 0.03$ & $0.512 \pm 0.017$ & $16.99 \pm 2.25$ \\
F2 & $26.61 \pm 0.98$ & $0.467 \pm 0.1$ & $0.551 \pm 0.1$ & $15.24 \pm 1.68$ \\
F3 & $28.24 \pm 0.86$ & $0.438 \pm 0.06$ & $0.510 \pm 0.08$ & $1.20 \pm 0.03$ \\
F4 & $29.55 \pm 1.09$ & $0.495 \pm 0.09$ & $0.590 \pm 0.04$ & $1.17 \pm 0.02$ \\
F5 & $30.59 \pm 1.19$ & $0.437 \pm 0.02$ & $0.530 \pm 0.015$ & $1.16 \pm 0.01$ \\
F6 & $31.18 \pm 1.36$ & $0.460 \pm 0.05$ & $0.553 \pm 0.03$ & $17.10 \pm 1.15$ \\
F7 & $26.13 \pm 1.06$ & $0.516 \pm 0.07$ & $0.610 \pm 0.06$ & $16.81 \pm 0.64$ \\
F8 & $30.67 \pm 1.43$ & $0.432 \pm 0.01$ & $0.525 \pm 0.02$ & $15.40 \pm 0.87$ \\
F9 & $26.35 \pm 1.23$ & $0.450 \pm 0.06$ & $0.532 \pm 0.05$ & $1.21 \pm 0.009$ \\
\hline
\end{tabular}

Values are represented as mean $\pm \mathrm{SD}(\mathrm{n}=3)$. SD: Standard deviation

Table 4: Physicochemical properties of compression-coated tablets

\begin{tabular}{|c|c|c|c|c|c|}
\hline $\begin{array}{l}\text { Formulation } \\
\text { code }\end{array}$ & Thickness \pm SD (cm) & Hardness $\pm S D\left(\mathrm{~kg} / \mathrm{cm}^{2}\right)$ & Friability \pm SD (\%) & $\begin{array}{l}\text { Weight } \\
\text { variation } \pm \text { SD }(\%)\end{array}$ & $\begin{array}{l}\text { Percentage } \\
\text { content } \pm \text { SD (\%) }\end{array}$ \\
\hline F1 & $0.574 \pm 0.05$ & $6.73 \pm 0.16$ & $0.45 \pm 0.01$ & \pm 2 & $99.79 \pm 0.36$ \\
\hline $\mathrm{F} 2$ & $0.596 \pm 0.07$ & $6.79 \pm 0.28$ & $0.35 \pm 0.07$ & \pm 1 & $99.96 \pm 0.23$ \\
\hline F3 & $0.579 \pm 0.83$ & $6.79 \pm 0.20$ & $0.39 \pm 0.08$ & \pm 1 & $99.95 \pm 0.51$ \\
\hline F4 & $0.592 \pm 0.53$ & $6.77 \pm 0.28$ & $0.43 \pm 0.02$ & \pm 1 & $99.74 \pm 0.56$ \\
\hline F5 & $0.563 \pm 0.44$ & $6.85 \pm 0.28$ & $0.32 \pm 0.09$ & \pm 2 & $98.87 \pm 0.38$ \\
\hline F6 & $0.582 \pm 0.13$ & $6.77 \pm 0.16$ & $0.39 \pm 0.03$ & \pm 1 & $99.34 \pm 0.12$ \\
\hline F8 & $0.576 \pm 0.07$ & $6.83 \pm 0.28$ & $0.35 \pm 0.08$ & \pm 1 & $99.02 \pm 0.14$ \\
\hline F9 & $0.581 \pm 0.10$ & $6.81 \pm 0.33$ & $0.37 \pm 0.01$ & \pm 1 & $99.97 \pm 0.33$ \\
\hline
\end{tabular}

Values are represented as mean \pm SD $(n=3)$. SD: Standard deviation

obtained from the pods of ladies finger. It has been extracted and used in the mucilaginous form. It is easily available and inexpensive. It is biodegradable, biocompatible, and also swelling properties. Okra gum as a binder produces some tablet formulations with good physicochemical properties, i.e., hardness, friability, disintegration time, etc. However, this binder may be considered as a good candidate for sustained release formulations. The method applied was compression coating since it offers several advantages over other methods. A superior coating is achieved without the hazards of solvents and the susceptible drug in the inner core also remains intact. Hence, this method was selected. Okra was used in various concentrations $(3 \%, 4 \%$, and $5 \% \mathrm{w} / \mathrm{w})$. The percentage of HPMCs in the outer coat was also varied. The results obtained from this study established the fundamental characteristics of okra gum, and due to its swelling ability, it can also be used in the food and cosmetic industry.

\section{AUTHORS' CONTRIBUTIONS}

Miss Shayeri Chatterjee, Lecturer, carried out the extraction, formulation, and in vitro characterization and drafted the manuscript. Mr. Rana Mazumder, Assistant Professor, designed the protocol, participated, and coordinated the study. All authors read and approved the final manuscript.

\section{ACKNOWLEDGMENT}

Authors wish to give thanks to Calcutta Institute of Pharmaceutical Technology and A.H.S. Howrah, West Bengal, India, authority for constant support and given research laboratory to carry out this project work. We also acknowledge the help provided by our fellow colleagues in completion of the project.

\section{CONFLICTS OF INTEREST}

The authors declare that they have no conflicts of interest.

\section{REFERENCES}

1. Krishna LN, Kulkarni PK, Dixit M, Lavanya D, Raavi PK. Brief introduction of natural gums, mucilages and their applications in novel drug delivery systems. Int J Drug Formulation Res 2011;2:54-71.

2. Nilesh J. A review on abelmoschus esculentus. Pharmacacia 2012;1:1-8.

3. Chickpetty SM, Baswaraj R, Nanjwade BK. Studies on development of novel combined time and $\mathrm{pH}$ dependent solvent less compression coated delivery systems for colonic delivery of diclofenac sodium. Asian J Pharm Clin Res 2010;3:110-3.

4. Malviya R. Extraction characterization and evaluation of selected mucilage as pharmaceutical excipient. Polim Med 2011;41:39-44.

5. Kulkarni GT, Gowthamarajan K, Rao B, Suresh B. Evaluation of binding properties of selected natural mucilages. J Sci Industrial Res 2002;61:529-32.

6. World Health Organization. Quality Control Methods for Medicinal Plant Materials. Geneva: WHO; 1998. p. 1-122.

7. Lala PK. Practical Pharmacognosy. Calcutta: Guha L; 1981. p. 135.

8. Malviya R, Srivastava P, Bansal M, Sharma PK. Preparation and evaluation of Curcubita maxima pulp powder. Int J Pharm Sci 2010;2:395-9.

9. Malviya R, Shukla P, Srivastava P. Preparation, characterization and evaluation of chitosan-gum Arabic coacervates as excipient in fast disintegrating/dissolving drug delivery system. FABAD J Pharm Sci 2009;34:213-23.

10. Kakade SM. Formulation and evaluation of mouth dissolving tablets of losartan potassium by direct compression techniques. Int J Res Pharm Sci 2010;1:290-5.

11. Aher BK, Bhavar BG, Joshi PH, Chaudhari RS. Recent advances incompression-coated tablets as a controlled drug delivery system. Saudi Pharm J 2011;2011:1-14 